\title{
Proposed Business Scheme for Small and Medium Architectural Consultant Using Blockchain Paradigm (Case Study: Studio Kano)
}

\author{
Jessica Chenriana and Alvanov Z. Mansoor
}

\section{ABSTRACT}

\begin{abstract}
Developments in Indonesia are growing along with the increase in population. The high demand both in architecture and construction is an excellent opportunity for architectural business. Unfortunately, the development was not supported by proper preparation of financial allocations. As a result, many projects were delayed or even stalled. Moreover, this problem has negative impacts on various parties, such as architects and contractors.
\end{abstract}

This paper formulates a new architectural business scheme for Studio Kano as a newcomer architectural consultant who often experiences problems during the process. The majority of this problem is due to the client's financial condition and causes a difference between the results and the initial design. At first, Studio Kano needs to increase the company's productivity and minimize disruption in project development, especially from the financial issues, by analyzing the company's current business situation using two analytical approaches; Business Process Analysis and Value Proposition.

The finding from conducted analysis determines a new architectural business scheme for Studio Kano using the Blockchain paradigm. It will underpin to maintain its design characteristics, maximize productivity, and minimize project development disruption, especially in payment issues.

Keywords: Architectural, Architectural Business, Business Process Analysis, Value Proposition, Blockchain Paradigm.

\section{INTRODUCTION}

In facing the increasing population in Indonesia, the number of people causes growth in development, whether in architecture or construction industry. The high demand for public and private facilities has become an excellent opportunity for developing the architecture business, especially architectural consultants, to meet human life needs. The contribution of architecture in the creative industry shows an interesting statistic. According to Mari Pangestu as the Minister of Tourism and Creative Economic, "The increase in architecture is the fourth highest than other creative industry sectors. This sector produces 36,659 workers and has the highest growth compared to other sectors by $17 \%$ [1].

However, several projects are often delayed and stalled due to the poor quality of project preparation and limited funding or financial allocations. Furthermore, this problem negatively impacted several parties involved, such as architects and contractors who suffered due to project delayed and stalled. Both small and medium projects have issues with financial conditions. For instance, building construction projects in Surakarta are hampered due to compensable delays in
Submitted : August 03, 2021

Published : August 28, 2021

ISSN: $2507-1076$

DOI: $10.24018 /$ ejbmr.2021.6.4.1025

\section{Jessica Chenriana*}

Bandung Institute of Technology, Bandung, West Java, Indonesia

(e-mail: jessica_chenriana@sbm-itb.ac.id) Alvanov Z. Mansoor

Bandung Institute of Technology,

Bandung, West Java, Indonesia

(e-mail: alvanov.zpalanzani@sbm-

itb.ac.id)

*Corresponding Author insufficient funds from the owner and the payment system that is not following the contract [2].

In responding to this problem, we would like to have a deeper understanding and solution by formulating a new architectural business scheme. This study may be helpful to increase the company's productivity and minimize disruption in project development from payment issues, especially in the client's financial condition.

\section{BUSINESS ISSUE EXPLORATION}

Studio Kano is an architectural consultant based in Bandung, Indonesia, focuses on designing residences, villas, restaurants, and cafes with a modern, simple and tropical design style. It was founded in 2020 by Jessica Chenriana and Tandean Jonathan. As a newcomer architectural consultant, Studio Kano has to have a specific business strategy to compete with its competitors. However, during the process, mainly in the construction stage, various problems often occur, such as changes in finishing materials and suddenly postponed projects. The majority of these problems are due to the client's financial condition, which causes a difference between the results and the initial design concept of Studio Kano. On the other hand, this is also detrimental for architects 
and the parties involved, such as contractors and other vendors, because of company productivity disruption. Therefore, it is necessary to analyze and get a new strategy.

Meanwhile, Studio Kano needs to maintain its service, quality, and design characteristics for existing customers despite external problems. To overcome these problems, Studio Kano proposes a new architectural business scheme starting with analyzing the company's current business situation using two analytical approaches; Business Process Analysis and Value Proposition.

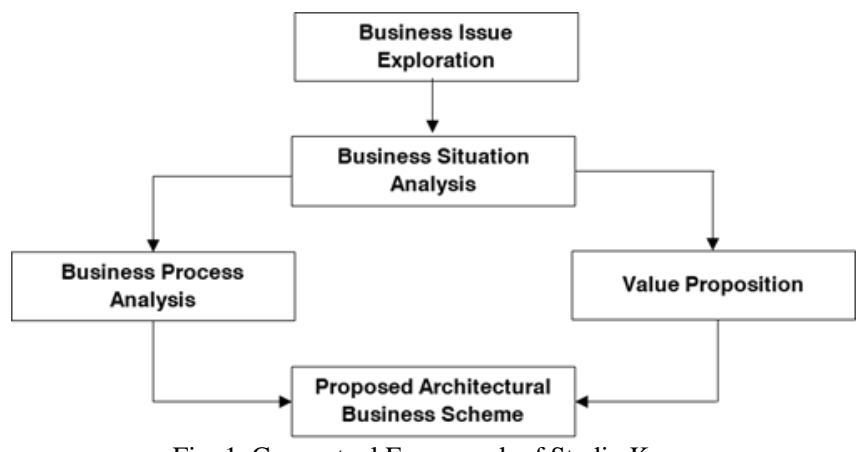

Fig. 1. Conceptual Framework of Studio Kano.

\section{A. Business Process Analysis}

A business process is a set of interrelated activities designed to produce an output for the customer. A company must have clear objectives, have input, have creation, use resources, have several activities which in several stages can affect more than one unit in the organization and can create value for consumers [3]. In addition, a great business process is one of the business strategies for a company to compete in the market [4].

The business process in architectural consultant covers all activities from initial briefs to construction drawings and the final design book. The following is a business process analysis from Studio Kano that consists of six steps.

TABLE I: BUSINESS PROCESS ANALYSIS

\begin{tabular}{|c|c|c|}
\hline Stages & Stakeholder & Problems \\
\hline Initial Brief & Architect, Client & $\begin{array}{c}\text { Design price bargaining } \\
\text { by clients }\end{array}$ \\
\hline $\begin{array}{c}\text { Design } \\
\text { Concept Proposal }\end{array}$ & Architect & Many design revisions \\
\hline $\begin{array}{c}\text { Design Development } \\
\text { Drawings }\end{array}$ & $\begin{array}{c}\text { Architect, Drafter, } \\
\text { 3D Artist }\end{array}$ & $\begin{array}{l}\text { Design revisions, } \\
\text { especially on finishing } \\
\text { and material changes }\end{array}$ \\
\hline $\begin{array}{l}\text { Construction } \\
\text { Drawings }\end{array}$ & $\begin{array}{c}\text { Architect, Drafter, } \\
\text { 3D Artist, MEP \& } \\
\text { Structure } \\
\text { Consultant, } \\
\text { Contractor }\end{array}$ & $\begin{array}{l}\text { Quantity of technical } \\
\text { drawings in a limited } \\
\text { time }\end{array}$ \\
\hline Start Construction & $\begin{array}{l}\text { Architect, } \\
\text { Contractor }\end{array}$ & $\begin{array}{l}\text { Finishing and material } \\
\text { change due to client's } \\
\text { estimated budget }\end{array}$ \\
\hline Final Project & Architect, Client & \\
\hline
\end{tabular}

The business process starts with the prospective clients showing an interest in using the architectural and interior design services of Studio Kano. In the early stages, both the client and the architect conduct an initial brief regarding the client's wishes and determine the design price. Unfortunately, there is often a bargain on the design price, which can cause the process has to stop at this stage if there is a discrepancy between the design price and the budget estimate. On the contrary, clients interested in continuing to the design stage will make a down payment.

Proceed to the next stage; Design Concept Proposal, the architect, provides the design concept, schematic drawings, and developed design for a permit. Nevertheless, there were many revisions related to the design. After that, the client makes the first payment before proceeding to the next step.

Entering Design Development Drawings stage, the architect provides the development of architectural drawings that consider all aspects of finishing and materials. The problem that often occurs is design revisions, especially on the finishing and material changes. At the end of this step, the client will pay the second payment before the architect proceeding to the construction drawings.

The next stage is the construction drawing; the architect develops detailed drawings for construction purposes. A large number of drawings output in a limited time is an obstacle in productivity for Studio Kano, which only consists of two workers. Thus, Studio Kano must hire a drafter by an outsourced system. Studio Kano also provides the selected contractor before the construction process begins. At the end of this step, the client makes the third payment for the architect.

After all the work drawings are completed, and the contractor has been selected, the next step is to start construction. It often happens in almost every Studio Kano projects that the clients change the finishing material to minimize the budget which causes the construction process to be hampered and affects the company's productivity. At last, Studio Kano does site supervision once a week and also provides detailed drawings for the contractor if needed. Lastly, the client makes full payment for the architect on the fourth payment.

The last step is the final project; Studio Kano provides the final design book to clients consists of all working drawings, detailed architectural drawings, and perspective rendering images.

In summary, problems often occur in almost every stage of the business analysis process. However, the most significant and frequent problem is the disruption of Studio Kano's productivity and construction delays due to the client's financial condition. There are often changes in finishing and materials at lower prices which cause differences between the results and the initial design concept.

\section{B. Value Proposition}

The value proposition describes services that offer value stated by a company to the customer segment. While the value proposition canvas diagram is a framework for ensuring that there is a match between the market and the product [6]. It consists of two parts; the customer segment and the value proposition. This diagram aims to determine the product's value based on consumer behavior to produce products according to market needs. To explain market needs, the researcher uses customer analysis data obtained from the evaluation results of communication between Studio Kano and existing customers. Customer analysis is an essential strategy in a marketing plan. Companies need to analyze customer data regarding needs, channels, problems, and other information required to obtain effective marketing strategies. 
In this study, the researcher analyzes the customer segment in the value proposition diagram by using customer analysis to determine customer jobs, customers' gains, and customers' pains, as follows.

TABLE II: CUSTOMER ANALYSIS

\begin{tabular}{cccccc}
\hline \hline Stages & Research & Contract & Implement & Closing & $\begin{array}{c}\text { After } \\
\text { Service }\end{array}$ \\
\hline Goals & $\begin{array}{c}\text { Find architectural } \\
\text { consultant }\end{array}$ & Get design idea & $\begin{array}{c}\text { Enjoy the } \\
\text { process }\end{array}$ & Satisfied & $\begin{array}{c}\text { Network, } \\
\text { experience }\end{array}$ \\
\hline Doing & $\begin{array}{c}\text { Ask family } \\
\& \text { friends }\end{array}$ & Deal, start payment & $\begin{array}{c}\text { Follow the } \\
\text { process }\end{array}$ & $\begin{array}{c}\text { Fill the } \\
\text { interior }\end{array}$ & Nice feedback \\
\hline People & $\begin{array}{c}\text { Family, friends, } \\
\text { contractor }\end{array}$ & Admin & Architect & Architect & $\begin{array}{c}\text { Return customer, } \\
\text { customer's friends }\end{array}$ \\
\hline Thinking & $\begin{array}{c}\text { Design to increase } \\
\text { value }\end{array}$ & $\begin{array}{c}\text { Price related } \\
\text { services }\end{array}$ & $\begin{array}{c}\text { On time } \\
\text { delivery }\end{array}$ & $\begin{array}{c}\text { The result } \\
\text { according to } \\
\text { design }\end{array}$ & $\begin{array}{c}\text { Should I } \\
\text { Recommend it? }\end{array}$ \\
\hline Experience & $\begin{array}{c}\text { Less portfolio, } \\
\text { lack of customer } \\
\text { trust }\end{array}$ & $\begin{array}{c}\text { Cannot relate } \\
\text { between price } \& \\
\text { project details }\end{array}$ & $\begin{array}{c}\text { Shifting } \\
\text { decision of } \\
\text { material used }\end{array}$ & $\begin{array}{c}\text { Incompatibilit } \\
\text { y with the } \\
\text { material color } \\
\text { or texture }\end{array}$ & $\begin{array}{c}\text { Not all projects } \\
\text { Comply with the } \\
\text { Initial design }\end{array}$ \\
\hline \hline
\end{tabular}

Customer jobs consist of problems and desires that consumers want (yellow points). In contrast, customers' gains are various things that are positive and provide the benefits expected by the customer (green points) and customers' pains are the opposite of customer gains, describes all negative and risks experienced by customers (red points). The following is the Value Proposition Canvas from Studio Kano.

TABLE III: VALUE PROPOSITION

\begin{tabular}{|c|c|c|}
\hline & Value Proposition & Customer Segment \\
\hline & Product and Services & Customers Job \\
\hline 1 & $\begin{array}{l}\text { Architectural design } \\
\text { services }\end{array}$ & $\begin{array}{c}\text { Functional: } \\
\text { Find architectural consultant Get } \\
\text { design idea Design to increase } \\
\text { value }\end{array}$ \\
\hline 2 & New acquaintance & Social: Networking \\
\hline \multirow[t]{2}{*}{3} & Good services & $\begin{array}{l}\text { Emotional: Experience \& enjoy } \\
\text { the process }\end{array}$ \\
\hline & Gain creators & Customer Gains \\
\hline 1 & $\begin{array}{c}\text { Various payment categories } \\
\text { based on services }\end{array}$ & Price related services \\
\hline 2 & Flexible project schedule & On time delivery \\
\hline \multirow[t]{2}{*}{3} & $\begin{array}{l}\text { Provide material sample, } \\
\text { site supervision services }\end{array}$ & The result according to the design \\
\hline & Pain Reliever & Customer Pains \\
\hline 1 & $\begin{array}{l}\text { Working process } \\
\text { explanation }\end{array}$ & $\begin{array}{l}\text { Cannot relate between price and } \\
\text { project details }\end{array}$ \\
\hline 2 & $\begin{array}{c}\text { Provide possible material } \\
\text { alternatives }\end{array}$ & Shifting decision of material used \\
\hline
\end{tabular}

\section{1) Customer Jobs - Product and Services}

Customer jobs are classified into three perspectives: functional, social, and emotional. In terms of functionality, the client finds an architectural consultant who can recognize their design expectations. In public buildings, a good design can increase the value of the building and affect sales growth. On the other hand, for private facilities such as residential houses, the plans support the clients' daily activities according to their needs and want. While, in the social perspective, the most impactful things are networks; the client also connects with contractors and other support vendors. Lastly is through the emotional aspect. Clients can get new experiences and enjoy the process.

Studio Kano helps customers complete the functional, social, and emotional tasks on customer jobs in company products and services. Studio Kano strives to always provide the best service by realizing client's needs and wants aesthetically and functionally. Furthermore, both the architect and the client can have new networking that can be mutually beneficial. For instance, architects will get more acquaintances and good references from clients, contractors, and supporting vendors. These acquaintances are also convenient to reach new potential clients. Lastly, by improving the quality of the service, it will also enhance the client experience.

\section{2) Customer Gains - Gains Creator}

In the architectural industry, price becomes critical in using a service. The client often has price bargaining because it is considered too expensive for the results obtained. In addition, on-time delivery in design and construction is essential because clients already have their targets that need to be achieved. Moreover, in the early design stages, the architect has provided design images to describe the building result. Thus the client has a view of the final result that must be following the initial design.

Responding to customer gains, the architect proposed to create various payment categories by classified them into three major stages; design, production, and post-production. Thus, there are no payments that are disruptive to the business processes. Furthermore, to complete the project on time, Studio Kano will provide a project schedule to determine the estimated time required to fulfill all design drawings before the construction phase begins. Lastly, it is necessary to provide material samples for specific products to minimize material changes by clients at the construction phase. The architect also needs to carry out site supervision to ensure everything goes according to the initial design.

\section{3) Customer Pains - Pain Reliever}

In this case, the most frequent customer pain experienced is in financial problems. The client often bids on the design cost due to financial issues. Moreover, there are often material changes, especially during the construction phase, because the material used in the design is not according to the estimated budget and causes Studio Kano's productivity and construction process to be hampered.

To counter the customer pains, the architect needs to explain that the working process requires effort and time to 
work optimally and get maximum results. At last, Studio Kano also needs to provide well-designed alternative materials with lower prices if there are change materials at the construction phase due to the client's estimated budget.

Based on the analysis results, Studio Kano found several factors that caused the project to be hampered, such as the difference between the results and the initial design due to the material changes with lower prices. In addition, bargaining on the design price is an obstacle for Studio Kano in maximizing its productivity. Thus, the leading cause of this problem is the client's financial condition, which affects performance and negatively impacts the parties involved, such as architects and contractors. Therefore, Studio Kano needs to create a new strategy in the production mechanism process as well as the payment terms system to minimize the current problems.

\section{BUSINESS STRATEGY FORMULATION}

\section{A. Proposed Architectural Business Scheme}

Based on the analysis results in the previous chapter, Studio Kano found that the main problems often occur due to the client's financial condition. Alongside the financial condition that often arises in almost every Studio Kano project, it also impacts the productivity and construction process. By determining the most suitable way to minimize the negative impact financially and in performance, Studio Kano proposed a new architectural business scheme using the basis of Blockchain paradigm. Blockchain is decentralized application stage and data sharing to participate, organize and cooperate in dynamic procedures [7]. It was chosen to be one of the Top Ten Emerging Technology trends, which is considered quite disruptive and can change the way business in various sectors [8]. In the industry community, Blockchain has become very important for sharing information and executing timely payment transactions. It can also create opportunities for collaboration between partners and suppliers, forming partnerships with professional organizations because of data transparency for all parties to access and create a timely and easy payment system [9]. In addition, Blockchain is often used to solve problems in collecting and integrating data. According to Sandy Rahmadika and Kyung-Hyune-Rhee's article about Blockchain technology in collecting effective data and ensuring data integration shows that the proposed approach is promising to be developed due to the high success rate [10]. Therefore, Studio Kano can hopefully produce a new architectural business scheme that affects its production mechanism process and payment terms.

Through the Blockchain paradigm, Studio Kano classified the process and payment terms into three major stages; design, production, and post-production. Firstly, the design stage consists of an initial brief and a design concept proposal. The production stage consists of design development drawings and construction drawings, while the post-production stage consists of construction and final projects. Each of these major stages has its payment terms that do not interfere with the other steps.

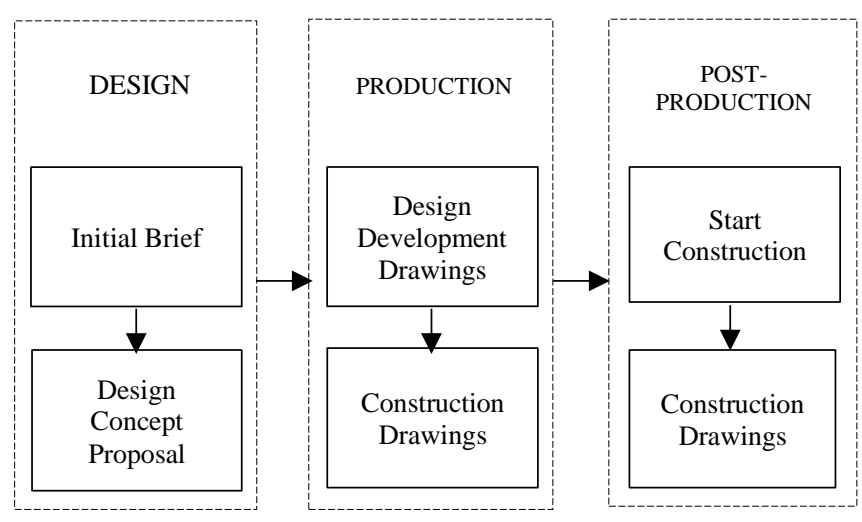

Fig. 2. Proposed Business Scheme Using Blockchain Paradigm.

By formulating this new business scheme, Studio Kano aims to increase productivity by minimizing factors that can prevent the work processes, such as material changes due to client financial problems. Thus, Studio Kano can maintain its simple, modern, and tropical design characteristics. Moreover, it is also helpful to simplify the working process in each step and the clients' payment terms. For instance, the architect has completed the design stage, but the client decided not to proceed to the production stage due to financial problems. The client has already made the payment for the architect at the first stage. Conversely, when the client already has a design drawing and requires the architect to proceed with the design development drawings or construction drawings, the process goes directly to the production stage as well as the payment terms. Lastly, this new business scheme has another positive impact. According to each step, Studio Kano can produce three portfolios, such as a design concept in the design stage, work drawings in the production stage, and a completed building project in the post-production stage.

\section{CONCLUSION}

The development process in Indonesia is not supported by good planning, especially in terms of financial problems, which have caused many construction projects to be stalled. This problem certainly has an impact on several parties involved, such as architects and contractors.

Meanwhile, the same problem occurs in almost every Studio Kano project. In the process, Studio Kano often encounters various issues. However, the most significant and frequent occurrence is from the payment issues, especially in the client's financial condition, disrupting the company's productivity and causes delayed projects.

Responding to the current problems, Studio Kano needs to create a new strategy in the production mechanism process as well as the payment terms system. Thus, the method proposed is offered a new architectural business scheme using the basis of Blockchain paradigm, which is suitable for Studio Kano problems because it becomes very important for sharing information and executing timely payment transactions.

At last, hopefully, Studio Kano can maintain its design characteristics by using this new strategy, maximize productivity, and minimize disruption in project development, especially in payment issues. 
European Journal of Business and Management Research www.ejbmr.org

\section{REFERENCES}

[1] N. J. Benu. Arsitektur, 5 Besar Penyumbang Industri Kreatif. 2012. Retrieved from: https://economy.okezone.com/read/2012/10/29/471/710765/arsitektur -5-besar-penyumbang-industri-kreatif.

[2] B. A. Nugroho. "Analisis Faktor Keterlambatan Proyek Terhadap Pembengkakan Biaya Proyek Bangunan Gedung di Surakarta," M.S Thesis, Dept. Civil. Eng., Sebelas Maret Univ., Surakarta, Indonesia, 2012.

[3] Sparx System.com. The Business Process Model. 2004. Retrieved from: https://sparxsystems.com/resources/tutorials/uml/businessprocess-model.html.

[4] C.E. Putri. Analisis Strategi Bisnis Pada PT. Omega Internusa Sidoarjo. Neliti. [Online]. 2017, pp 01. Available: https://media.neliti.com/media/publications/57198-ID-none.pdf.

[5] A. Ozterwalder. Value Proposition Design. Hoboken, New Jersey: John Wiley \& Sons, Inc., 2014.

[6] W. Saputra. Customer Analysis. 2009. Retrieved from http://wiryasaputra.blogspot.com/2009/12/customer-analysis.html.

[7] S. Rahmadika and K.H. Rhee. (August 2018). Blockchain Technology for Providing an Architecture Model of Decentralized Personal Heatlh Information. Sage Journal. [Online]. pp. 01. Available: https://journals.sagepub.com/doi/pdf/10.1177/1847979018790589.

[8] Daily Social.com, Membuat Nyata Blockchain untuk Bisnis. 2017. Retrieved from: https://dailysocial.id/post/membuat-nyata-blockchainuntuk-bisnis.

[9] KFA Architect and Planners.com. Why is Blockchain Useful in The Building Industry? 2021. Retrieved from: http://kfarchitecture.com/blockchain.

[10] K. R. Pardeshi, Deepak, and P. Pareekh. (June, 2021). Review of Blockchain Architecture A Survey. Journal of Composition Theory. [Online]. pp 239. Available:

https://www.researchgate.net/profile/Komal-

Pardeshi/publication/352213267_REVIEW_OF_BLOCKCHAIN_AR CHITECTURE_A_SURVEY/links/60bf4c07299bf10dffa6efa5/REVI EW-OF-BLOCKCHAIN-ARCHITECTURE-A-SURVEY.pdf.

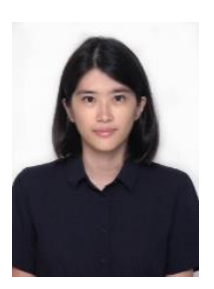

Jessica Chenriana was born on April 28, 1995, in Bandung, Indonesia. Graduated from Architecture at Parahyangan Catholic University in 2017. She continued her Master degree in Master of Business Administration program at Bandung Institute of Technology and graduated in 2021. Currently as an entrepreneur and architect, she would like to deepen her career and business in the architectural industry.

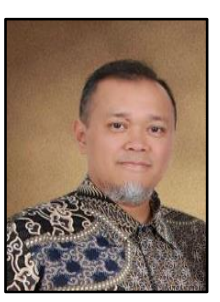

Alvanov Z. Mansoor was born on November 27,1974 in Bandung, Indonesia. In 2012, he completed his doctoral program in Bandung Institute of Technology majoring in Art and Design studies after graduated from Master of Management program, Telkom University in 2005. His expertise in research are cultural studies, media studies, visual storytelling, and creative business. Dr. Mansoor is currently works as lecturer, researcher, boardgame designer, creative business and visual storytelling. Dr. Mansoor is eager to contribute in cross and multidiscipline studies and various creative projects. 